\title{
IMPLEMENTASI PEMBELAJARAN MATEMATIKA DENGAN PENDEKATAN OPEN ENDED TERHADAP SIKAP SISWA
}

\author{
Neneng Tita Rosita ${ }^{1}$, Agus Jaenudin ${ }^{2}$ \\ Program Studi Pendidikan Matematika \\ STKIP Sebelas April Sumedang \\ titayusepa79@gmail.com ${ }^{1}$,ghoesjen@yahoo.com ${ }^{2}$
}

\begin{abstract}
Abstrak: Penelitian ini merupakan penelitian kuasi eksperimen yang mengkaji penerapan pembelajaran matematika dengan pendekatan Open Ended terhadap sikap siswa.Data pada penelitian ini diperoleh dari angket yang diisi oleh siswa setelah mendapatkan pembelajaran matematika dengan pendekatanOpen Ended.Angket skala sikap yang digunakan merujuk kepada skala Likert.Berdasarkan hasil penelitian yang telah dilakukan diperoleh kesimpulan bahwa penerapan pembelajaran matematika dengan pendekatan Open Ended memberikan pengaruh positif terhadap sikap siswa.

Kata kunci: Pendekatan Open Ended, Sikap Siswa, Skala Likert.
\end{abstract}

\section{A. PENDAHULUAN}

Matematika sebagai ilmu yang timbul karena pikiran-pikiran manusia yang berhubungan dengan ide, proses, dan penalaran Ruseffendi (1988), membutuhkan siasat atau strategi dalam pembelajarannya, agar muncul kemampuan untuk menggunakan pengetahuan, keterampilan, prinsip, aturan dan konsep-konsep yang berkaitan dengan mata pelajaran tersebut.Matematika secara umum memiliki fungsi sebagai bahasa, sebagai cara berfikir nalar dan sebagai alat untuk memecahkan masalah. Sementara itu di dalam Kurikulum Tingkat Satuan Pendidikan (KTSP) sertaBadanStandarNasionalPendidikan (BSNP) (2006:1), pembelajaran matematika bertujuan agar siswa dapat menggunakan matematika sebagai cara bernalar (berpikir logis, analisis, sistematis, kritis, kreatif, dan kemampuan bekerja sama).

Lebih lanjut salah satu tujuan diberikannya mata pelajaran matematika tersebut dirinci untuk setiap jenjang pendidikan yang bertujuan agar siswa memiliki kemampuanmemiliki sikap menghargai kegunaan matematika dalam kehidupan, yaitu memiliki rasa ingin tahu, perhatian, dan minat dalam mempelajari matematika, serta sikap ulet dan percaya diri dalam pemecahan masalah (BSNP, 2006).

Sikap merupakan salah satu komponen dari aspek afektif, yang merupakan kecenderungan seseorang untuk merespon positif atau negatif suatu objek, situasi, konsep, atau kelompok rangsangan dari luar diri seseorang.Sikap siswa terhadap matematika dapat berupa sikap positif yang dapat membantu siswa untuk menghargai mata pelajaran matematika dan membantu siswa mengembangkan rasa percaya diri terhadap kemampuan dirinya, sedangkan sikap negatif tidak dapat membantu siswa untuk 
menghargai mata pelajaran matematika dan tidak dapat membantu siswa mengembangkan rasa percaya diri terhadap kemampuan dirinya.

Agar dapat menumbuhkan sikap positif terhadap matematika, diperlukan suatu pendekatan dalam menyampaikan pembelajaran yang dapat meningkatkan sikap siswa atau membuat siswa bersikap positif terutama pada pelajaran matematika, guru dapat menyajikan model pembelajaran yang bernuansa pemecahan masalah dan berpandangan konstruktivisme. Salah satu variasi pembelajaran yang diharapkan mampu menumbuhkan sikap positif siswa adalah pendekatan open-ended.

Sikap siswa terhadap pembelajaran dengan pendekatan open-ended dapat dipandang sebagai cerminan proses pembelajaran yang terjadi di kelas. Penyampaian materi pelajaran matematika perlu diperhatikan agar pembelajaran dapat menyenangkan, mudah dipahami dan tidak menakutkan. Oleh sebab itu materi harus dipilih dan disesuaikan berkaitan dengan kehidupan sehari-hari dan tingkat kognitif siswa. Penyajian materi pelajaran matematika dimulai dengan menyajikan masalah terbuka, dan diawali dengan pertanyaaan-pertayaan terbuka yang mengundang siswa menjawab pertanyaan tersebut sesuai dengan ide-ide atau gagasan-gagasan siswa, hal ini sesuai dengan karakteristik dari pendekatan open-ended. Bila hal ini diperhatikan dalam proses pembelajaran, bukan mustahil sikap positif siswa terhadap pembelajaran yang diikuti akan tumbuh.

Berdasarkan uraian diatas maka penelitian ini difokuskan pada pengkajian implementasi pembelajaran matematika dengan pendekatan openended terhadap sikap siswa.

\section{Sikap Siswa}

Pendidikan matematika memiliki tujuan antara lain mengupayakan aspek pembentukan sikap. Proses pembelajaran matematika yang dilaksanakan perlu mempertimbangkan sikap positif siswa terhadap matematika. Hal tersebut penting, menurut Djadir (Haji : 2005) sikap positif terhadap matematika perlu diperhatikan karena berkaitan positif dengan prestasi belajar matematika. Siswa yang suka terhadap matematika memiliki prestasi yang cukup tinggi dan sebaliknya, siswa yang tidak menyukai matematika prestasinya cenderung rendah.

Sikap positif siswa merupakan salah satu tujuan dalam pembelajaran matematika. Menurut Russefendi (1988)Sikap positif siswa terhadap pembelajaran mempunyai ciri-ciri siswa mengikuti pelajaran dengan sungguhsungguh, menyelesaikan tugas dengan baik, berpartisipasi aktif dalam diskusi, mengerjakan tugas-tugas rumah dengan tuntas dan selesai pada waktunya, dan merespon dengan baik tantangan yang datang dari bidang studi tersebut.

Sikap merupakan salah satu komponen dari aspek afektif, yang merupakan kecenderungan seseorang untuk merespon positif atau negatif suatu objek, situasi, konsep, atau kelompok rangsangan dari luar diri sesesorang.Thorndike dan Hagen(Haji, 2005), menyatakan sikap sebagai suatu kecenderungan untuk menerima atau menolak kelompok-kelompok individu, atau institusi sosial tertentu. Atiken (Ma, 1997) melukiskan sikap sebagai 
kecendengan seseorang untuk merespon secara positif atau negatif suatu objek, situasi, konsep, atau orang lain.

Sikap seseorang terhadapmatematika dapat diukur dengan menggumnakan angket sikap dengan skala Likert. Menurut Fennema dan Sherman (Ruseffendi, 1986) Sikap terhadap matematika dapat diukur berdasarkan indikator-indikator yaitu: a) kepercayaan diri dalam belajar matematika; b) kecemasan dalam belajar matematika; c) Kegunaan matematika, d) sikap terhadap keberhasilan; e) dorongan untuk berhasil dalam matematika; f) persepsi terhadap sikap dan dorongan guru matematika; g) matematika hanya cocok untuk pria; h) persepsi terhadap sikap dan dorongan ayah; i) persepsi terhadap terhadap sikap dan dorongan ibu.

\section{Pendekatan Open-Ended}

Pendekatan open-ended membahas dan memecahkan masalah, sebagaimana yang dilakukan dalam problem solving dan problem posing. Asumsinya adalah, proses lebih utama dari pada hasil. Kedua pendekatan tersebut menekankan pada upaya pemecahan masalah, dengan merumuskan permasalahannya terlebih dahulu. Dalam pendekatanopen-ended terdapat keragaman dalam penyelesaian ataupun metode penyelesaiannya. Pendekatan openended memberi keleluasaan kepada siswa untuk mengemukakan jawaban. Dalam konteks ini, pendekatan open-ended lebih bersifat merangsang kreativitas cara berpikir siswa.

Pendekatan open-ended merupakan salah satu pendekatan yang membantu siswa melakukan problem solving secara kreatif dan menghargai keragaman berpikir yang mungkin timbul selama proses problem solving. Dalam proses pembelajaran dengan pendekatan open-ended, biasanya digunakan soal-soal open-ended sebagai instrumen dalam pembelajaran.

Beberapa peneliti mendefinisikan soal open-ended sebagai berikut: Hancock (1995) mengatakan bahwa soal open-ended adalah soal yang memiliki lebih dari satu penyelesaian yang benar. Pertanyaan open-ended sering diartikan sebagai pertanyaan yang mempunyai jawaban yang benar lebih dari satu. Siswa menjawab pertanyaan dengan caranya sendiri yang tidak mengikuti proses pengerjaan jawaban yang sudah ada. Selanjutnya Shimada (1997) mengatakan bahwa pendekatan open-ended adalah pendekatan pembelajaran yang menyajikan suatu permasalahan yang memiliki metode atau penyelesaian yang benar lebih satu, sehingga dapat memberi kesempatan kepada siswa untuk memperoleh pengetahuan/pengalaman menemukan, mengenali, dan memecahkan masalah dengan beberapa teknik.. Lebih lanjut Yaniawati (2002) menyatakan keleluasaan berpikir melalui pendekatan openended membawa siswa untuk lebih memahami suatu topik dan keterkaitannya dengan topik lainnya, baik dalam pelajaran matematika maupun dengan mata pelajaran lain dan dalam kehidupan sehari-hari.

Pembelajaran dengan pendekatan open-endeddiawali dengan memberikan masalah terbuka kepada siswa. Kegiatan pembelajaran harus mengarah dan mengantarkan siswa dalam menjawab masalah dengan banyak cara serta mungkin juga dengan banyak jawaban benar, sehingga merangsang 
kemampuan intelektual dan pengalaman siswa dalam proses menemukan sesuatu yang baru.

Nohda (Suherman, 2001) mengatakan bahwa tujuan pembelajaran open-ended adalah untuk membantu mengembangkan kegiatan kreativitas dan pola pikir matematika melalui problem solving secara simultan. Untuk mengembangkan kreativitas, siswa diberi keleluasaan untuk mengemukakan ide atau gagasan semaksimal mungkin sesuai dengan kemampuan siswa itu sendiri. Dengan demikian pembelajaran open-ended dapat diartikan sebagai pembelajaran yang membangun kegiatan interaktif siswa dengan materi bahan ajar, sehingga muncul ide untuk mengembangkan strategi pemecahan masalah yang dihadapi.

Ada beberapa karakteristik dalam pembelajaran open-endedyang dapat dikembangkan, yaitu berupa kegiatan yang sifatnya terbuka, memandang matetamatika sebagai ragam berpikir, dan keterpaduan antara siswa dengan matematika.Terbuka berarti siswa dapat secara bebas berimpropisasi melakukan kegiatan belajar sesuai dengan jalan pikirannya.Ragam berpikir diartikan bahwa dalam kegiatan pembelajaran matematika dengan open-ended adalah berbagai macam kegiatan berpikir yang biasa dilatih dan dibiasakan.Keterpaduan dimaksudkan adalah kebebasan siswa untuk berpikir dalam upaya memecahkan masalah sesuai dengan kemampuan, sikap, minat, dan kondisi emosinya.

Dalam pelaksanaan pembelajaran dengan pendekatan open-ended, disusun dengan langkah-langkah sebagai berikut: (1) Menyajikan masalah; (2) Mengorganisasikan pembelajaran; (3) Memperhatikan dan mencatat respon siswa; dan (4) Menyimpulkan.

Beberapa keunggulan pendekatan open-ended, menurut Tim MKPBM (2001:121) diantaranya sebagai berikut: (1) Siswa berpartisipasi lebih aktif dalam pembelajaran dan serius mengekspresikan idenya; (2) Siswa memiliki kesempatan lebih banyak dalam memanpaatkan pengetahuan dan keterampilan matematika secara komperhensif; (3) Siswa dengan kemampuan matematika rendah dapat merespon permasalahan dengan cara mereka sendiri; (3) Siswa secara intrinstik termotivasi untuk memberikan bukti atau penjelasan. (4) Siswa memiliki pengalaman banyak untuk menemukan sesuatu dalam menjawab permasalahan.

Menyimak kelebihan-kelebihan dari penerapan soal-soal open-ended, maka sangat tepat sekiranya dijadikan salah satu sarana untuk menumbuhkan sikap positif siswa terhadap matematika dan meningkatkan kreativitas siswa di samping kemampuan berpikir divergen sebagai salah satu unsur pembangunnya.

\section{B. METODE PENELITIAN}

Tujuan penelitian ini adalah untuk melihat penerapan pendekatan pembelajaran open-ended terhadap sikap siswa. Disain penelitian ini adalah "kuasi-eksperimen". Menurut Russefendi (1994) pada kuasi eksperimen ini subjek tidak dikelompokkan secara acak, tetapi menerima keadaan subjek apa 
adanya. Penggunaan disain seperti ini dilakukan dengan pertimbangan bahwa, kelas yang sudah terbentuk sebelumnya, sehingga tidak dilakukan lagi pengelompokkan secara acak. Pembentukkan kelas baru hanya akan menyebabkan kekacauan jadwal pelajaran yang sudah ada di sekolah. Penelitian ini melibatkan satu kelas yang diberikan perlakuan berupa pembelajaran matematika dengan pendekatan open ended.Pembelajaran dilakukan selama 6 (enam) pertemuan.

Populasi dari penelitian ini adalah seluruh siswa kelas VII di salah satu SMP Negeri di Kabupaten Bandung.Sebagai subyek sampel, dipilih secara acak kelas (random kelas) sebanyak satu kelas dari 9 kelas.

Instrumen yang digunakan pada penelitian ini adalah instrumen non-tes berupa angket skala sikap siswa. Skala sikap siswa bertujuan untuk mengetahui sikap siswa terhadappembelajaran matematika melalui pendekatan open-ended. Model skala yang digunakan adalah model skala Likert. Arikunto (2009) mengemukakan bahwa skala Likert disusun dalam bentuk suatu pernyataan dan diikuti oleh lima respon yang menunjukkan tingkatan, yaitu: sangat setuju (SS), setuju (S), tidak berpendapat (TB), tidak setuju (TS), dan sangat tidak setuju (STS).Dalam penelitian ini, kelima respon tersebut digunakan semuanya. Dalam menganalisis hasil skala sikap ini, skala kualitatif tersebut ditransfer ke dalam skala kuantitatif. Pemberian nilainya dibedakan antara pernyataan yang bersifat negatif dengan pernyataan yang bersifat positif. Untuk pernyataan yang bersifat positif, pemberian skornya adalah SS diberi skor 5, S diberi skor 4, TB diberi skor 3, TS diberi skor 2, dan STS diberi skor 1. Sedangkan untuk pernyataan negatif, pemberian skornya adalah SS diberi skor 1, S diberi skor 2, TB diberi skor 3, TS diberi skor 4, dan STS diberi skor 5.

Angket skala siswa yang telah disusun telah mendapat pertimbangan dari sebanyak3 orang teman sejawat peneliti, yakni dosen pendidikan matematika STKIP Sebelas April Sumedang. Pertimbangan yang diminta menyangkut isi dan bahasa yang digunakan.

Dalam menganalisis hasil angket skala sikap siswa, data kualitatif yang telah diperoleh ditransfer terlebih dahulu ke dalam data kuantitatif. Data hasil penelitian angket dihitung dengan menggunakan rumus sebagai berikut:

a. Menghitung rata-rata skor tiap siswa

$$
\bar{x}=\frac{x_{t}}{p}
$$

Keterangan:

$\bar{x}$ : rata-rata skor siswa

$x_{t}$ : jumlah skor siswa

$p$ : jumlah pernyataan

b. Menghitung rata-rata total

$\bar{x}=\frac{\sum x_{t}}{n}$

$\bar{x}$ : rata-rata skor siswa

$\sum x_{t}=$ jumlah rata-rata total

$n$ : jumlah siswa 
Kategori Angkat sesuai skala Likert

\begin{tabular}{|c|l|}
\hline Skor rata-rata total & Kriteria \\
\hline $1 \leq x_{t}<3$ & Negatif \\
$x_{t}=3$ & Netral \\
$3<x_{t} \leq 5$ & Positif \\
\hline
\end{tabular}

\section{HASIL PENELITIAN}

Analisis sikap siswa dilakukan terhadap pembelajaran matematika dengan cara mengukur data hasil angket sikap siswa terhadap matematika dan pembelajaran dengan pendekatan open-ended. Perhitungan skala sikap siswa ini menggunakan bantuan Microsoft Office Excel 2007

Dalam mendeskripsikan sikap siswa terhadap pembelajaran matematika setelah mendapatkan pembelajaran dengan pendekatan openended, seperti telah dijelaskan di atas, bahwa pada penelitian ini skor sikap siswa,data kualitatif yang telah diperoleh ditransfer terlebih dahulu ke dalam data kuantitatif, hasilnya terlihat di Tabel 1.

Tabel 1

Hasil Penilaian Skala Sikap

\begin{tabular}{|c|c|c|c|c|c|c|c|c|}
\hline \multirow{2}{*}{$\begin{array}{l}\text { No } \\
\text { Soal }\end{array}$} & \multirow{2}{*}{$\begin{array}{l}\text { Sifat } \\
\text { Pernyataan }\end{array}$} & \multicolumn{5}{|c|}{ Jawaban } & \multirow[t]{2}{*}{$\bar{x}$} & \multirow[t]{2}{*}{$\overline{x_{t}}$} \\
\hline & & SS & $\mathbf{S}$ & $\mathbf{N}$ & TS & STS & & \\
\hline \multirow[b]{2}{*}{1} & \multirow{2}{*}{ Positif } & 6 & 18 & 12 & 0 & 0 & \multirow[t]{2}{*}{3,8} & \multirow[t]{19}{*}{3,78} \\
\hline & & $16,67 \%$ & $50,00 \%$ & $33,33 \%$ & $0,00 \%$ & $0,00 \%$ & & \\
\hline \multirow[b]{2}{*}{2} & \multirow{2}{*}{ Positif } & 5 & 14 & 12 & 5 & 0 & \multirow[t]{2}{*}{3,6} & \\
\hline & & $13,89 \%$ & $38,89 \%$ & $33,33 \%$ & $13,89 \%$ & $0,00 \%$ & & \\
\hline \multirow[b]{2}{*}{3} & \multirow{2}{*}{ Negatif } & 0 & 2 & 1 & 18 & 15 & \multirow[t]{2}{*}{4,3} & \\
\hline & & $0,00 \%$ & $5,56 \%$ & $2,78 \%$ & $50,00 \%$ & $41,67 \%$ & & \\
\hline \multirow[b]{2}{*}{4} & \multirow{2}{*}{ Negatif } & 2 & 8 & 11 & 7 & 8 & \multirow[t]{2}{*}{3,3} & \\
\hline & & $5,56 \%$ & $22,22 \%$ & $30,56 \%$ & $19,44 \%$ & $22,22 \%$ & & \\
\hline \multirow[b]{2}{*}{5} & \multirow{2}{*}{ Positif } & 5 & 19 & 10 & 2 & 0 & \multirow[t]{2}{*}{3,8} & \\
\hline & & $13,89 \%$ & $52,78 \%$ & $27,78 \%$ & $5,56 \%$ & $0,00 \%$ & & \\
\hline \multirow[b]{2}{*}{6} & \multirow{2}{*}{ Negatif } & 0 & 11 & 7 & 14 & 4 & \multirow[t]{2}{*}{3,2} & \\
\hline & & $0,00 \%$ & $30,56 \%$ & $19,44 \%$ & $38,89 \%$ & $11,11 \%$ & & \\
\hline \multirow[b]{2}{*}{7} & \multirow{2}{*}{ Negatif } & 0 & 2 & 4 & 17 & 13 & \multirow[t]{2}{*}{4,1} & \\
\hline & & $0,00 \%$ & $5,56 \%$ & $11,11 \%$ & $47,22 \%$ & $36,11 \%$ & & \\
\hline \multirow[b]{2}{*}{8} & \multirow{2}{*}{ Negatif } & 0 & 12 & 13 & 8 & 3 & \multirow[t]{2}{*}{3,1} & \\
\hline & & $0,00 \%$ & $33,33 \%$ & $36,11 \%$ & $22,22 \%$ & $8,33 \%$ & & \\
\hline \multirow{3}{*}{9} & \multirow{2}{*}{ Positif } & 12 & 16 & 6 & 1 & 1 & \multirow[t]{2}{*}{4,1} & \\
\hline & & $33,33 \%$ & $44,44 \%$ & $16,67 \%$ & $2,78 \%$ & $2,78 \%$ & & \\
\hline & Positif & 14 & 19 & 2 & 1 & 0 & 4,3 & \\
\hline
\end{tabular}




\begin{tabular}{|c|c|c|c|c|c|c|c|}
\hline 10 & & $38,89 \%$ & $52,78 \%$ & $5,56 \%$ & $2,78 \%$ & $0,00 \%$ & \\
\hline \multirow[b]{2}{*}{11} & \multirow{2}{*}{ Negatif } & 0 & 1 & 1 & 15 & 19 & \multirow[t]{2}{*}{4,4} \\
\hline & & $0,00 \%$ & $2,78 \%$ & $2,78 \%$ & $41,67 \%$ & $52,78 \%$ & \\
\hline \multirow[b]{2}{*}{12} & \multirow{2}{*}{ Positif } & 26 & 9 & 1 & 0 & 0 & \multirow[t]{2}{*}{4,7} \\
\hline & & $72,22 \%$ & $25,00 \%$ & $2,78 \%$ & $0,00 \%$ & $0,00 \%$ & \\
\hline \multirow[b]{2}{*}{13} & \multirow{2}{*}{ Positif } & 23 & 9 & 3 & 1 & 0 & \multirow[t]{2}{*}{4,5} \\
\hline & & $63,89 \%$ & $25,00 \%$ & $8,33 \%$ & $2,78 \%$ & $0,00 \%$ & \\
\hline \multirow[b]{2}{*}{14} & \multirow{2}{*}{ Negatif } & 0 & 1 & 5 & 18 & 12 & \multirow[t]{2}{*}{4,1} \\
\hline & & $0,00 \%$ & $2,78 \%$ & $13,89 \%$ & $50,00 \%$ & $33,33 \%$ & \\
\hline \multirow[b]{2}{*}{15} & \multirow{2}{*}{ Negatif } & 0 & 2 & 11 & 17 & 6 & \multirow[t]{2}{*}{3,8} \\
\hline & & $0,00 \%$ & $5,56 \%$ & $30,56 \%$ & $47,22 \%$ & $16,67 \%$ & \\
\hline \multirow[b]{2}{*}{16} & \multirow{2}{*}{ Negatif } & 0 & 0 & 5 & 21 & 10 & \multirow[t]{2}{*}{4,1} \\
\hline & & $0,00 \%$ & $0,00 \%$ & $13,89 \%$ & $58,33 \%$ & $27,78 \%$ & \\
\hline \multirow[b]{2}{*}{17} & \multirow{2}{*}{ Positif } & 10 & 16 & 8 & 0 & 2 & \multirow[t]{2}{*}{3,9} \\
\hline & & $27,78 \%$ & $44,44 \%$ & $22,22 \%$ & $0,00 \%$ & $5,56 \%$ & \\
\hline \multirow[b]{2}{*}{18} & \multirow{2}{*}{ Positif } & 8 & 20 & 8 & 0 & 0 & \multirow[t]{2}{*}{4,0} \\
\hline & & $22,22 \%$ & $55,56 \%$ & $22,22 \%$ & $0,00 \%$ & $0,00 \%$ & \\
\hline \multirow[b]{2}{*}{19} & \multirow{2}{*}{ Negatif } & 1 & 2 & 13 & 11 & 9 & \multirow[t]{2}{*}{3,7} \\
\hline & & $2,78 \%$ & $5,56 \%$ & $36,11 \%$ & $30,56 \%$ & $25,00 \%$ & \\
\hline & Docitif & 9 & 23 & 3 & 1 & 0 & 4,1 \\
\hline 20 & 10siti & $25,00 \%$ & $63,89 \%$ & $8,33 \%$ & $2,78 \%$ & $0,00 \%$ & \\
\hline & & 1 & 1 & 1 & 22 & 11 & 4,1 \\
\hline 21 & 1vegatil & $2,78 \%$ & $2,78 \%$ & $2,78 \%$ & $61,11 \%$ & $30,56 \%$ & \\
\hline & & 12 & 17 & 5 & 2 & 0 & 4,1 \\
\hline 22 & 10sitil & $33,33 \%$ & $47,22 \%$ & $13,89 \%$ & $5,56 \%$ & $0,00 \%$ & \\
\hline & & 10 & 20 & 5 & 1 & 0 & 4,1 \\
\hline 23 & 10sitil & $27,78 \%$ & $55,56 \%$ & $13,89 \%$ & $2,78 \%$ & $0,00 \%$ & \\
\hline & Notof & 6 & 4 & 12 & 9 & 5 & 3,1 \\
\hline 24 & & $16,67 \%$ & $11,11 \%$ & $33,33 \%$ & $25,00 \%$ & $13,89 \%$ & \\
\hline & P.i. & 11 & 11 & 14 & 0 & 0 & 3,9 \\
\hline 25 & Fositil & $30,56 \%$ & $30,56 \%$ & $38,89 \%$ & $0,00 \%$ & $0,00 \%$ & \\
\hline & Notof & 1 & 3 & 16 & 11 & 5 & 3,4 \\
\hline 26 & 1Vegatil & $2,78 \%$ & $8,33 \%$ & $44,44 \%$ & $30,56 \%$ & $13,89 \%$ & \\
\hline & Doritif & 7 & 24 & 5 & 0 & 0 & 4,1 \\
\hline 27 & rosili & $19,44 \%$ & $66,67 \%$ & $13,89 \%$ & $0,00 \%$ & $0,00 \%$ & \\
\hline & & 1 & 1 & 20 & 9 & 5 & 3,5 \\
\hline 28 & Negatif & $2,78 \%$ & $2,78 \%$ & $55,56 \%$ & $25,00 \%$ & $13,89 \%$ & \\
\hline
\end{tabular}




\begin{tabular}{|c|c|c|c|c|c|c|c|}
\hline \multirow[b]{2}{*}{29} & \multirow{2}{*}{ Positif } & 6 & 22 & 6 & 2 & 0 & \multirow[t]{2}{*}{3,9} \\
\hline & & $16,67 \%$ & $61,11 \%$ & $16,67 \%$ & $5,56 \%$ & $0,00 \%$ & \\
\hline \multirow[b]{2}{*}{30} & \multirow{2}{*}{ Positif } & 7 & 20 & 9 & 0 & 0 & \multirow[t]{2}{*}{3,9} \\
\hline & & $19,44 \%$ & $55,56 \%$ & $25,00 \%$ & $0,00 \%$ & $0,00 \%$ & \\
\hline \multirow[b]{2}{*}{31} & \multirow{2}{*}{ Positif } & 7 & 18 & 11 & 0 & 0 & \multirow[t]{2}{*}{3,9} \\
\hline & & $19,44 \%$ & $50,00 \%$ & $30,56 \%$ & $0,00 \%$ & $0,00 \%$ & \\
\hline \multirow[b]{2}{*}{32} & \multirow{2}{*}{ Positif } & 10 & 20 & 5 & 1 & 0 & \multirow[t]{2}{*}{4,1} \\
\hline & & $27,78 \%$ & $55,56 \%$ & $13,89 \%$ & $2,78 \%$ & $0,00 \%$ & \\
\hline
\end{tabular}

\section{PEMBAHASAN DAN KESIMPULAN}

Berdasarkan hasil yang diperoleh dari pengisian angket skala sikap pada Tabel 1 di atas dapat memberikan gambaran umum tentang pendapat siswa terhadap diterapkannya pembelajaran matematika melalui pendekatan open-ended, hasilnya diperoleh rata-rata total sebesar 3,78 artinya siswa memiliki respon positif terhadap Matematika. Respon siswa terhadap pembelajaran open-endeddengan aspek-aspeknya dapat dijabarkan sebagai berikut:

a. Kepercayaan diri dalam belajar matematika

Berdasarkan hasil analisis data skala sikap pada Tabel 1 pada aspek mampu menumbuhkan kepercayaan diri dalam belajar matematika, butir pernyataan pada aspek tersebut terdapat pada nomor pernyataan $1,3,4,5,8$, diperoleh rata-rata terbesar 4,3 yang menunjukkan sifat negatif "Matematika hanya cocok untuk anak pandai saja" sebanyak 91,6\% siswa menyatakan sikap sangat tidak setuju (STS), dan tidak setuju (TS). Hal ini menunjukan bahwa semua siswa berhak dan harus belajar matematika. Sedangkan rata-rata terkecil 4,3 yang menunjukkan sifat negatif "Matematika hanya cocok untuk anak pandai saja" sebanyak $91,6 \%$ siswa menyatakan sikap sangat tidak setuju (STS), dan tidak setuju (TS). Hal ini menunjukan bahwa semua siswa berhak dan harus belajar matematika.

\section{b. Kecemasan dalam belajar matematika}

Aspek kecemasan dalam dalam belajar matematika dapat diungkap melalui pernyataan nomor 2,6 dan 7. Diperoleh rata-rata terbesar 4,1 pada pernyataan nomor 7 yang menunjukkan sifat negatif "Perasaan takut gagal, membuat saya malas untuk belajar matematika" sebanyak 83,33\% siswa menyatakan sikap sangat tidak setuju (STS), dan tidak setuju (TS). Hal ini menunjukan sebagian besar siswa tidak setuju terhadap pernyataan bahwa perasaan takut gagal, membuatnya malas untuk belajar matematika. Sedangkan rata-rata terkecil 3,2 pada pernyataan nomor 6 yang menunjukkan sifat negatif "Matematika hanya cocok untuk anak pandai saja" sebanyak 91,6\% siswa menyatakan sikap sangat tidak setuju (STS), dan tidak setuju (TS). Hal ini menunjukan bahwa semua siswa berhak dan harus belajar matematika. 


\section{c. Kegunaan matematika}

Aspek kegunaan matematika dapat diungkap melalui pernyataan nomor 9, 10 dan 11. Diperoleh rata-rata terbesar 4,4 pada yang menunjukkan sifat negatif "materi matematika tidak memberikan manfaat bagi kehidupan " sebanyak 94,45\% siswa menyatakan sikap sangat tidak setuju (STS), dan tidak setuju (TS). Hal ini menunjukan sebagian besar siswa tidak setuju terhadap pernyataan bahwa matematika tidak ada manfaatnya bagi kehidupan, hal ini berarti matematika berguna bagi kehidupan sehari-hari.Sedangkan rata-rata terkecil 4,1 yang menunjukkan sifat positif "saya menyenangi matematika karena sebagian besar pekerjaan orang menggunakan matematika" sebanyak $77,77 \%$ siswa menyatakan sikap sangat setuju (SS), dan setuju (S). Hal ini menunjukan bahwa sebagian besar siswa menyenangi matematika karena sebagian besar pekerjaan orang menggunakan matematika.

d. Sikap terhadap keberhasilan

Aspek sikap terhadap keberhasilan dapat diungkap melalui pernyataan nomor $12,13,14$ dan 15.Diperoleh rata-rata terbesar 4,4 pada yang menunjukkan sifat negatif "materi matematika tidak memberikan manfaat bagi kehidupan" sebanyak 94,45\% siswa menyatakan sikap sangat tidak setuju (STS), dan tidak setuju (TS). Hal ini menunjukan sebagian besar siswa tidak setuju terhadap pernyataan bahwa matematika tidak ada manfaatnya bagi kehidupan, hal ini berarti matematika berguna bagi kehidupan sehari-hari. Sedangkan rata-rata terkecil 4,1 yang menunjukkan sifat positif "saya menyenangi matematika karena sebagian besar pekerjaan orang menggunakan matematika" sebanyak 77,77\% siswa menyatakan sikap sangat setuju (SS), dan setuju (S). Hal ini menunjukan bahwa sebagian besar siswa menyenangi matematika karena sebagian besar pekerjaan orang menggunakan matematika.

e. Dorongan untuk berhasil dalam matematika

Aspek dorongan untuk berhasil dalam matematika dapat diungkap melalui pernyataan nomor 16, 17, 18 dan 19. Diperoleh rata-rata terbesar 4,4 pada yang menunjukkan sifat negatif "materi matematika tidak memberikan manfaat bagi kehidupan " sebanyak 94,45\% siswa menyatakan sikap sangat tidak setuju (STS), dan tidak setuju (TS). Hal ini menunjukan sebagian besar siswa tidak setuju terhadap pernyataan bahwa matematika tidak ada manfaatnya bagi kehidupan, hal ini berarti matematika berguna bagi kehidupan sehari-hari. Sedangkan rata-rata terkecil 4,1 yang menunjukkan sifat positif "saya menyenangi matematika karena sebagian besar pekerjaan orang menggunakan matematika" sebanyak $77,77 \%$ siswa menyatakan sikap sangat setuju (SS), dan setuju (S). Hal ini menunjukan bahwa sebagian besar siswa menyenangi matematika karena sebagian besar pekerjaan orang menggunakan matematika.

f. Persepsi terhadap sikap dan dorongan guru

Aspek persepsi terhadap sikap dan dorongan guru dapat diungkap melalui pernyataan nomor 20, 21 dan 22.Diperoleh rata-rata terbesar 4,4 pada yang menunjukkan sifat negatif "materi matematika tidak memberikan 
manfaat bagi kehidupan " sebanyak 94,45\% siswa menyatakan sikap sangat tidak setuju (STS), dan tidak setuju (TS). Hal ini menunjukan sebagian besar siswa tidak setuju terhadap pernyataan bahwa matematika tidak ada manfaatnya bagi kehidupan, hal ini berarti matematika berguna bagi kehidupan sehari-hari. Sedangkan rata-rata terkecil 4,1 yang menunjukkan sifat positif "saya menyenangi matematika karena sebagian besar pekerjaan orang menggunakan matematika" sebanyak 77,77\% siswa menyatakan sikap sangat setuju (SS), dan setuju (S). Hal ini menunjukan bahwa sebagian besar siswa menyenangi matematika karena sebagian besar pekerjaan orang menggunakan matematika.

g. Persepsi terhadap pembelajaran dengan pendekatan open ended

Aspek persepsi terhadap pembelajaran dengan pendekatan open-ended dapat diungkap melalui pernyataan nomor 23, 24, 25, 27, dan 28.Diperoleh rata-rata terbesar 4,4 pada yang menunjukkan sifat negatif "materi matematika tidak memberikan manfaat bagi kehidupan " sebanyak 94,45\% siswa menyatakan sikap sangat tidak setuju (STS), dan tidak setuju (TS). Hal ini menunjukan sebagian besar siswa tidak setuju terhadap pernyataan bahwa matematika tidak ada manfaatnya bagi kehidupan, hal ini berarti matematika berguna bagi kehidupan sehari-hari. Sedangkan rata-rata terkecil 4,1 yang menunjukkan sifat positif "saya menyenangi matematika karena sebagian besar pekerjaan orang menggunakan matematika" sebanyak $77,77 \%$ siswa menyatakan sikap sangat setuju (SS), dan setuju (S). Hal ini menunjukan bahwa sebagian besar siswa menyenangi matematika karena sebagian besar pekerjaan orang menggunakan matematika.

h. Persepsi terhadap keragaman jawaban atas suatu persoalan

Aspek persepsi terhadap keragaman jawaban atas suatu persoalan dapat diungkap melalui pernyataan nomor 26, 29, 30, dan 32. Diperoleh ratarata terbesar 4,4 pada yang menunjukkan sifat negatif "materi matematika tidak memberikan manfaat bagi kehidupan " sebanyak 94,45\% siswa menyatakan sikap sangat tidak setuju (STS), dan tidak setuju (TS). Hal ini menunjukan sebagian besar siswa tidak setuju terhadap pernyataan bahwa matematika tidak ada manfaatnya bagi kehidupan, hal ini berarti matematika berguna bagi kehidupan sehari-hari. Sedangkan rata-rata terkecil 4,1 yang menunjukkan sifat positif "saya menyenangi matematika karena sebagian besar pekerjaan orang menggunakan matematika" sebanyak $77,77 \%$ siswa menyatakan sikap sangat setuju (SS), dan setuju (S). Hal ini menunjukan bahwa sebagian besar siswa menyenangi matematika karena sebagian besar pekerjaan orang menggunakan matematika.

Dari uraian diatas dapat disimpulkan bahwa pembelajaran matematika dengan pendekatan open-ended dapat menumbuhkan sikap positif terhadap matematika.

Sikap terhadap matematika merupakan kecenderungan seseorang untuk menerima atau menolak matematika. Sikap terhadap matematika dapat dilihat saat siswa mengikuti pembelajaran matematika, mengerjakan tugas matematika dan hal lainnya yang menyangkut pembelajaran matematika. 
Berdasarkan hasil penelitian, pengolahan data, analisis, temuan dan pembahasan yang telah disajikan di atas, diperoleh kesimpulan sikap siswa terhadap pembelajaran matematika sangat positif. Sehingga perlu lebih ditingkatkan lagi agar prestasi yang dicapai lebih baik lagi, hal ini dikarenakankeberhasilan pembelajaran matematika tidak dapat dipisahkan dari berbagai faktor yang mempengaruhinya, salah satunya adalah faktor yang berasal dari siswa yang biasa disebut karakteristik siswa. Sikap siswa terhadap matematika merupakan salah satu bagian dalam karakteristik siswa yang tidak dapat diabaikan dalam pembelajaran matematika.

\section{E. REFERENSI}

Badan Standar Nasiona Pendidikan (2006). Panduan Penyusunan Kurikulum Tingkat Satuan Pendidikan Jenjang Pendidikan Dasar dan Menengah. Jakarta: BSNP.

Dahlan, J.A (2004). Meningkatkan Kemampuan Penalaran dan Pemahaman Matematik Siswa SLTP melalui Pendekatan Open-Ended. Disertasi PPS UPI. Bandung: Tidak Diterbitkan.

Haji, S (2005). Pengaruh Pendekatan Matematika Realistik terhadap Hasil Belajar Matematika di Sekolah Dasar. Disertasi Doktor pada PPS UPI: Tidak dipublikasikan.

Hancock, C.L (1995). "Enhancing Mathematics Learning with Open Ended Queations". Assesment Standard for School Mathematics. 86(9).

Ma, X (1997). "Assessing the Relationship Between Attitude Toward Mathematics and Achievement in Mathematics. A Meta-Analysis". Journal for Research in Mathematics Education, 28(1). 26-47.

Ruseffendi, E.T (1998). Statistik Dasar untuk Penelitian Pendidikan. Bandung: IKIP Bandung Press.

Ruseffendi, E.T (1994). Dasar- Dasar Penelitian Pendidikan dan Bidang NonEksakta Lainnya. Semarang: IKIP Semarang Press.

Ruseffendi, E.T (1988). Pengantar kepada Membantu Guru Mengembangkan Kompetensinya dalam Pengajaran Matematika untuk Meningkatkan CBSA. Bandung : Tarsito.

Sawada, Toshio. (1997). Developing Lesson Plans. The significance of an OpenEnded Approach. The Open-Ended Approach : A New Proposal for Teaching Mathematics. Tokyo. Japan

Shimada, S. (1997). The Significance of an Open-Ended Approach. The Open-Ended Appoach : A New Proposal for Teaching Mathematics. Tokyo. Japan.

Sudjana (2001). Penilaian Hasil Pembelajaran. Bandung: PT Remaja Rosdakarya.

Sudjana (1989). Metode Statistika. Bandung: Tarsito.

Sugiyono (2010). Metode Penelitian Pendidikan. Bandung: Alfabeta.

Sukmadinata, N.S(2004). Kurikulum dan Pembelajaran Kompetensi. Bandung Kesuma Karya . 
Suherman, E(2004). Model-Model Pembelajaran Matematika. Bandung: LPMP Jawa Barat.

Suherman, E. dkk. (2001). Strategi Pembelajaran Matematika Kontemporer. Bandung: JICA UPI.

Wahyudin (1999). Kemampuan Guru Matematika, Calon Guru Matematika, dan Siswa dalam Mata Pelajaran Matematika. Disertasi Doktorpada FPS UPI. Bandung : tidak diterbitkan

Wardhani,S dan Rumiati(2011). Instrumen Penilaian Hasil Belajar Matematika SMP: Belajar dari PISA dan TIMSS. Yogyakarta : Kementrian Pendidikan Nasional : Pusat Pengembangan dan Pemberdayaan Pendidik dan Tenaga Kependidikan Matematika.

Yaniawati, P. (2001). Pembelajaran dengan Pendekatan Open Ended dalam Upaya Meningkatkan Kemampuan Koneksi Matematika. Disertasi. PPS UPI. Bandung: Tidak diterbitkan. 